\title{
The Quality of \\ Three Table Grape Varieties Fumigated with Methyl Bromide at Doses Recommended for the Control of Mealybugs
}

\author{
J.L. Smilanick, ${ }^{1}$ F. M likota, ${ }^{2}$ \\ P.L. H artsell, ${ }^{3}$ J.S. M uhareb, ${ }^{4}$ \\ and N. Denis-Arrue
}

Additional Index words. Vitis vinifera, Planococcusficus, Pseudococcus maritimus

Summary. 'R uby Seedless', 'Red G lobe', and 'Prima Red' table grapes were fumigated with the treatment schedule of the U SD A-A nimal Plant $H$ ealth Inspection Service recommended for the control of mealybugs. M ethyl bromide was applied at 64 $\mathrm{g} \cdot \mathrm{m}^{-3}\left(4.0 \mathrm{lb} / 1000 \mathrm{ft}^{3}\right)$ for $2 \mathrm{~h}$ at 16.1 to $18.3^{\circ} \mathrm{C}\left(61\right.$ to $\left.65^{\circ} \mathrm{F}\right)$. T he grapes were in commercial packages typical for each cultivar. After fumigation and $\mathbf{3 0} \mathrm{min}$ of aeration, the grapes were stored 2 to 4 weeks at $5{ }^{\circ} \mathrm{C}$ (41 ${ }^{\circ} \mathrm{F}$ ) and their quality assessed by evaluation of cluster rachis condition, shatter, berry cracking, decay, berry color, internal browning, bleaching injury, and firmness. N one of the table grape quality parameters was significantly influenced by methyl bromide fumigation.

The cost of publishing this paper was defrayed in part by the payment of page charges. U nder postal regulations, this paper therefore must be hereby marked adverti sement solely to indicate this fact.

${ }^{1}$ Research plant pathologist, U SD A-ARS, 2021 South Peach Avenue, $\mathrm{H}$ orticultural $\mathrm{C}$ rops Research $\mathrm{L}$ aboratory, Fresno CA 93727

${ }^{2}$ R esearch associate, Institute for Adriatic C rops, Split Croatia.

${ }^{3}$ Chemist, DFA of California, 1855 South Van Ness, Fresno CA 93721

${ }^{4}$ Chemist, DFA of California, 1855 South Van N ess, Fresno CA 93721.

${ }^{5}$ Biological technician, U SD A-ARS, 2021 South Peach Avenue, $\mathrm{H}$ orticultural Crops Research Laboratory, Fresno CA 93727. 
T able 1. Q uality parameters and methods employed to evaluate table grape quality after methyl bromide fumigation.

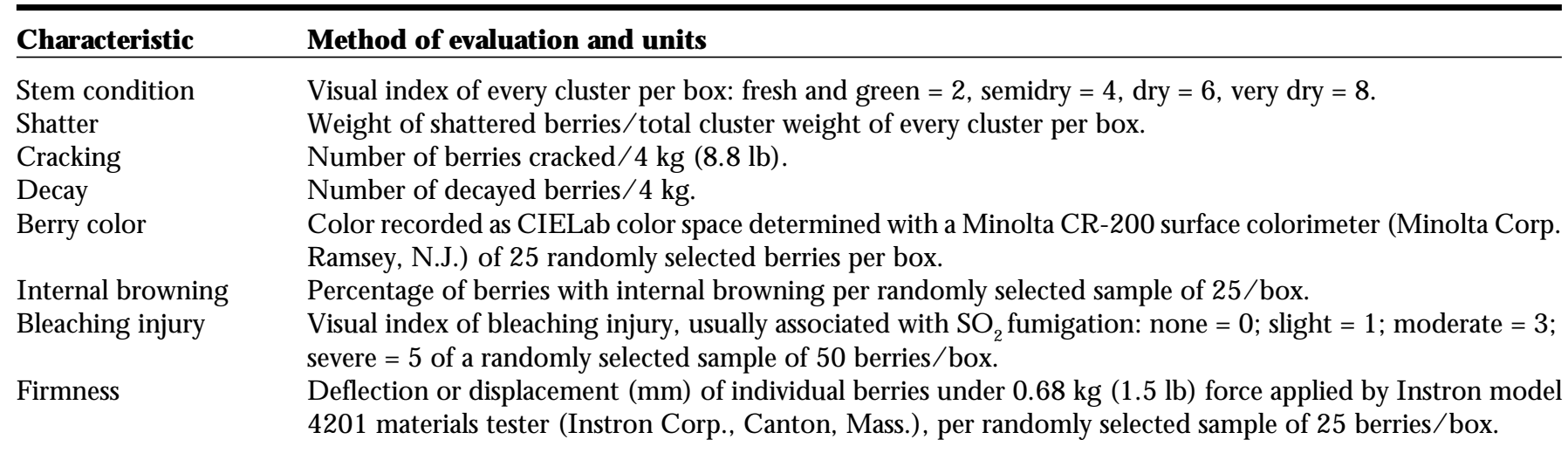

$\mathrm{R}$ ecently, Australia required U.S. shippers to fumigate table grapes exported to that country to control two pests of quarantine concern, the grape mealybug (Pseudococcusmariti mus) and vinemealybug (Planococcusficus) using aU SD AAnimal Plant H ealth I nspection Service (U SD A-APH IS) mealybug fumigation schedule developed for quarantine purposes (U SD A-APH IS 1996). Both of these pests occur in the San Joaquin Valley of California. TheU SD A-APH IS fumigation schedule for mealybug control dictatesahigher methyl dosage, but of shorter duration, than that routinely used for fruit fly (C eratitissp.) control. Chilean grapesimported into theU nited States are routinely fumigated with methyl bromideusing thefruitfly schedule and impacts on grape quality are minor. The fumigation schedule applied for fruit fly control is $32 \mathrm{~g} \cdot \mathrm{m}^{-3}$ (2 $\mathrm{lb} / 1000 \mathrm{ft}^{3}$ ) for $3.5 \mathrm{~h}$, while that for mealybug control is $64 \mathrm{~g} \cdot \mathrm{m}^{-3}(4 \mathrm{lb} /$ $1000 \mathrm{ft}^{3}$ ) for $2 \mathrm{~h}$. This results in a concentration $\times$ time product $\approx 12.5 \%$ higher in the Australian quarantine requirement than for fruit fly fumigation. Exporters are concerned about the impact the mealybug schedule may have on grape quality. Therefore, we conducted a thorough assessment of the influence of thisschedule on tablegrape quality to determine if negative impacts on berry quality might result from itsuse.
The primary injury caused by methyl bromide to table grapes is internal browning (Auda et al., 1977; N elson and Spitler 1982). Phillips and coworkers (1984) reported $32 \mathrm{~g} \cdot \mathrm{m}^{-3}(2 \mathrm{lb} /$ $1000 \mathrm{ft}^{3}$ ) methyl bromide for $3.5 \mathrm{~h}$ did not cause internal browning or other injuriesto tablegrapes. $\mathrm{H}$ owever, $\mathrm{N}$ elson and Spitler (1982) reported that this rate increased the incidence of internal browning of 'Thompson Seedless' berries when fumigation was four or more hours. Liyanage and coworkers (1993) showed glutathione content wasgreatly reduced by methyl bromide fumigation, although they did not demonstrate a causative relationship between glutathione reduction and internal browning. O ur objective was to evaluate the quality of several popular table grape varieties ('Red Globe', 'Prima Red', and 'Ruby Seedless') after fumigation with $64 \mathrm{~g} \cdot \mathrm{m}^{-3}\left(4 \mathrm{lb} / 1000 \mathrm{ft}^{3}\right)$ of methyl bromide for $2 \mathrm{~h}$.

\section{Materials and methods}

The table grapes were obtained from commercial cold storage ( 0 to 1 ${ }^{\circ} \mathrm{C}$; 32 to $34^{\circ} \mathrm{F}$ ); they had been harvested 2 monthspreviously and had $\mathrm{SO}_{2}$ generator pads within each package. TheSO generatorswereremoved from one-half of the 'Prima Red' and 'Red Globe' packages and all of the 'Ruby Seedless' packages. 'Red Globe' grapes were in expanded polystyrene (EPS) boxes with microperforated plastic liners[perforations: 1-mm-diameter (0.04inch) holes spaced $10 \mathrm{~mm}$ (0.4 inch) apart] with no internal packaging around the clusters. 'Prima Red' grapes were in expanded EPS boxes, with the same perforated plastic liners, and the clusters were wrapped in tissue paper. 'Ruby Seedless' grapes were in technical kraft veneer (TKV) boxes, the box had a vented paper curtain and no plastic liner, and the clusterswere wrapped in vented plastic bags.

Two boxes of each combination of variety and package type were fumigated. Thetablegrapeswerefumigated in a 0.54$\mathrm{m}^{3}\left(19.1 \mathrm{ft}^{3}\right)$ steel chamber at DFA of Californiain Fresno, California. Thischamber exceeds all USDA-APHIS performance requirements for quarantinetreatments. The treatment schedule used was USDA-APH IS Schedule T104(a²) for mealybugs. M ethyl bromide was applied at $64 \mathrm{~g} \cdot \mathrm{m}^{-3}\left(4.0 \mathrm{lb} / 1000 \mathrm{ft}^{3}\right)$ for $2 \mathrm{~h}$ followed by aeration for $30 \mathrm{~min}$.

The load factor in the chamber was higher with 'Red Globe' and 'PrimaRed' grapes than 'Ruby Seedless' grapes. Four boxes of each variety were used within the chamber in tests with 'Red Globe' and 'PrimaRed' grapes, which occupied $\approx 25 \%$ of the chamber volume (vol/ vol). Two boxeswerefumigated within thechamber in tests with 'Ruby Seedless' grapes and these occupied $\approx 8.1 \%$ of the chamber volume (vol/ vol).

T able 2. C oncentrations and sorption of methyl bromide determined during fumigation tests on table grapes using U SD A-APH IS treatment schedule for mealybugs $\left(1.0 \mathrm{~g} \cdot \mathrm{m}^{-3}=1.0 \mathrm{oz} / 1000 \mathrm{ft}^{3}\right)$.

\begin{tabular}{lccccccc}
\hline & \multicolumn{7}{c}{ Methyl bromide $\left(\mathbf{g} \cdot \mathbf{m}^{-\mathbf{3}}\right)^{\mathbf{z}}$} \\
\cline { 2 - 8 } Cultivar & Initial & $\mathbf{0 . 5} \mathbf{~ h}$ & $\mathbf{1 ~ h}$ & $\mathbf{2 ~ h}$ & Sorption (\%) & $\mathbf{1 5} \mathbf{~} \mathbf{~}$ in & $\mathbf{3 0} \mathbf{~ m i n}$ \\
\hline Prima Red & 72.0 & 65.4 & 61.2 & 50.0 & 30.6 & 11.1 & 2.7 \\
Red Globe & 75.1 & 64.0 & 58.4 & 53.0 & 29.4 & 5.6 & 1.4 \\
Ruby Seedless & 66.2 & 64.0 & 60.4 & 58.4 & 11.8 & 9.7 & 4.1 \\
\hline
\end{tabular}

zM ethyl bromide concentration inside chamber during aeration.

yPercentage of original methyl bromide concentration remaining after 2 hours before aeration began. 
T able 3. Q uality measurements (means \pm SD) of table grapes after methyl bromide fumigation. The methods of evaluation and units of each measurement are described in Table $1 . \mathrm{G}$ rapes were stored 2 months at $0^{\circ} \mathrm{C}\left(32{ }^{\circ} \mathrm{F}\right.$ ) before fumigation and 2 weeks at $5{ }^{\circ} \mathrm{C}\left(41{ }^{\circ} \mathrm{F}\right)$ plus $1 \mathrm{~d}$ at $20^{\circ} \mathrm{C}\left(68^{\circ} \mathrm{F}\right)$ after fumigation ( $1.0 \mathrm{~mm}=0.039 \mathrm{inch}$ ).

\begin{tabular}{|c|c|c|c|c|c|c|c|c|c|c|c|}
\hline \multirow[b]{2}{*}{ C ultivar } & \multirow{2}{*}{$\begin{array}{l}\mathrm{SO}_{2} \\
\text { pad }\end{array}$} & \multirow{2}{*}{$\begin{array}{c}\text { Stem } \\
\text { condition }\end{array}$} & \multirow[b]{2}{*}{ Shatter } & \multirow{2}{*}{$\begin{array}{c}\text { C racking } \\
\text { (no.) }\end{array}$} & \multirow{2}{*}{$\begin{array}{l}\text { Decay } \\
\text { (no.) }\end{array}$} & \multicolumn{3}{|c|}{ B erry color } & \multirow{2}{*}{$\begin{array}{c}\text { Internal } \\
\text { browning }(\%)^{z}\end{array}$} & \multirow{2}{*}{$\begin{array}{l}\text { B leaching } \\
\text { injury } \\
\end{array}$} & \multirow{2}{*}{$\begin{array}{l}\text { Firmness } \\
(\mathrm{mm})\end{array}$} \\
\hline & & & & & & $\mathbf{L}$ & $\mathbf{a}$ & b & & & \\
\hline Ruby Seedless-CO N ${ }^{y}$ & yo & $3.5 \pm 0.5$ & $0.7 \pm 0.1$ & $1.5 \pm 1.1$ & $4.7 \pm 2.6$ & $28.9 \pm 1.2$ & $6.7 \pm 1.3$ & $1.9 \pm 0.9$ & 14 & $3.0 \pm 1.4$ & $3.2 \pm 0.4$ \\
\hline Ruby Seedless-M B & no & $3.3 \pm 0.7$ & $0.7 \pm 0.1$ & $1.7 \pm 0.9$ & $3.8 \pm 1.6$ & $28.9 \pm 1.1$ & $6.3 \pm 1.6$ & $1.8 \pm 1.4$ & 18 & $2.8 \pm 1.4$ & $3.3 \pm 0.4$ \\
\hline $\operatorname{LSD}_{(P=0.05)}$ & & $N S^{x}$ & NS & NS & NS & NS & NS & NS & NS & NS & NS \\
\hline Red Globe-CON & yes & $4.5 \pm 0.6$ & $0.1 \pm 0.1$ & $0.3 \pm 0.5$ & $1.8 \pm 1.9$ & $32.0 \pm 1.8$ & $13.6 \pm 2.7$ & $4.5 \pm 1.5$ & 6 & $3.0 \pm 1.4$ & $2.4 \pm 0.5$ \\
\hline Red Globe-M B & yes & $4.4 \pm 0.2$ & 0 & $0.1 \pm 0.2$ & $0.8 \pm 0.6$ & $31.1 \pm 1.5$ & $12.2 \pm 2.6$ & $3.8 \pm 1.5$ & 8 & $2.8 \pm 1.4$ & $2.5 \pm 0.4$ \\
\hline Red Globe-CON & no & $4.2 \pm 0.6$ & 0 & $0.1 \pm 0.2$ & $0.6 \pm 0.9$ & $32.7 \pm 1.8$ & $13.4 \pm 2.0$ & $4.5 \pm 1.2$ & 8 & $2.7 \pm 1.4$ & $3.5 \pm 0.4$ \\
\hline Red Globe-M B & no & $4.2 \pm 0.8$ & $0.1 \pm 0.1$ & $0.4 \pm 0.7$ & $0.8 \pm 1.5$ & $31.6 \pm 1.7$ & $12.1 \pm 3.0$ & $3.7 \pm 1.3$ & 14 & $2.3 \pm 1.4$ & $2.5 \pm 0.3$ \\
\hline $\operatorname{LSD}_{(P=0.05)}$ & & NS & NS & NS & NS & NS & NS & NS & NS & NS & NS \\
\hline Prima Red-CON & yes & $3.6 \pm 0.6$ & $0.6 \pm 0.1$ & $0.8 \pm 1.0$ & $1.8 \pm 1.7$ & $29.3 \pm 1.6$ & $7.9 \pm 1.6$ & $2.9 \pm 1.1$ & 78 & $2.7 \pm 1.8$ & $3.1 \pm 0.6$ \\
\hline Prima Red-M B & yes & $3.6 \pm 0.4$ & $0.8 \pm 0.1$ & $0.6 \pm 0.5$ & $1.2 \pm 1.7$ & $29.6 \pm 1.9$ & $8.1 \pm 1.5$ & $3.4 \pm 1.4$ & 74 & $2.9 \pm 1.3$ & $2.9 \pm 0.5$ \\
\hline Prima Red CON & no & $4.1 \pm 0.7$ & $0.6 \pm 0.1$ & $0.5 \pm 0.5$ & $1.7 \pm 0.8$ & $29.4 \pm 1.1$ & $7.8 \pm 1.3$ & $2.5 \pm 0.8$ & 90 & $2.4 \pm 1.4$ & $3.0 \pm 0.6$ \\
\hline Prima Red-M B & no & $3.6 \pm 0.5$ & $0.7 \pm 0.1$ & $0.5 \pm 0.5$ & $0.8 \pm 0.9$ & $29.3 \pm 1.2$ & $8.4 \pm 1.4$ & $2.6 \pm 0.8$ & 78 & $2.2 \pm 1.4$ & $3.0 \pm 0.4$ \\
\hline $\operatorname{LSD}_{(P=0.05)}$ & & NS & NS & NS & NS & NS & NS & NS & NS & 0.4 & NS \\
\hline
\end{tabular}

${ }^{\mathrm{z}}$ Evaluated after 4 weeks at $5^{\circ} \mathrm{C}\left(41^{\circ} \mathrm{F}\right)$ after fumigation.

${ }^{y} \mathrm{CON}=$ untreated control; $\mathrm{MB}=$ methyl bromide fumigated.

ss $M$ eans within columns are nonsignificant.

Methyl bromide concentrations during fumigation and aeration were determined by gas chromatography. Samples were withdrawn with a gastight syringe and introduced viaan integral gas-sampling valve ( $1 \mathrm{~mL}$ loop) into agaschromatograph (model 1200; Fisher, Pittsburgh, $\mathrm{Pa}$.) using thermal conductivity for detection. The temperatures of the column, detector, and valve were $150\left(302^{\circ} \mathrm{F}\right), 170\left(338^{\circ} \mathrm{F}\right)$, and $170^{\circ} \mathrm{C}\left(338^{\circ} \mathrm{F}\right)$, respectively. The helium carrier gas flow rate through the $1.8 \mathrm{~m}$ ( $5.9 \mathrm{ft}$ ) long by $4 \mathrm{~mm}$ ( $0.16 \mathrm{inch})$ diameter Poropak Q column (M illipore Corp., Bedford, M ass.) was $25 \mathrm{~mL} \cdot \mathrm{min}^{-1}$ $(0.85 \mathrm{fl} \mathrm{oz} / \mathrm{min})$ and the retention time for methyl bromide was $1.9 \mathrm{~min}$.

Table grape quality was assessed 2 weeks after fumigation and storage at 5 ${ }^{\circ} \mathrm{C}\left(41^{\circ} \mathrm{F}\right)$, and one additional day at 20 ${ }^{\circ} \mathrm{C}\left(68^{\circ} \mathrm{F}\right)$ by evaluation of cluster stem or rachiscondition, shatter, berry cracking, decay, berry color, bleaching injury, and firmness. Internal browning wasassessed after 2 to 4 weeks of storage at $5^{\circ} \mathrm{C}$. Therewere two boxestreated of each combination of variety and package type. The sampling methods, qualitycharacteristicsevaluated, and theunits employed are described in Table 1.

Analysis of variance was applied to the units of measurement employed in each quality evaluation. The responses of each 'Red Globe' and 'Prima Red' cultivars were analyzed independently in atwo (fumigated or not fumigated) $\times$ two (with sulfur dioxide generator pad orwithout) design; 'Ruby Seedless' were analyzed in a one-way design. Results from all cultivars were combined in a three-way analysisof varianceto identify significant differences among them. If significant, Fisher's protected least significant difference was calculated $(P=$ 0.05 ) to separate treatment means.

\section{Results}

The fumigation simulated a commercial fumigation that would be applied for the control of mealybugs for quarantine purposes. Table 2 showsthe concentration of methyl bromide during the exposure period and aeration.
The readings initially were higher than the dose calculated for an empty chamber which indicated chamber volume displaced by the packages. The minimum methyl bromide concentrations asspecified by theU SD A-APH IS at 0.5 and $2.0 \mathrm{~h}$ were exceeded. The methyl bromide concentrations during aeration, shown in T able2, dropped rapidly and simulated aeration that would occur under commercial conditions. EPS boxes adsorbed more methyl bromide than TKV boxes. The grape and air temperatures during fumigation were 16.1 to $18.3^{\circ} \mathrm{C}\left(61\right.$ to $\left.65^{\circ} \mathrm{F}\right)$ and were within the specifications of USDAAPH IS for mealybug fumigation.

No quality parameter of the table grapes was significantly influenced by methyl bromide fumigation (T able 3). Sulfur dioxidepadssignificantlyincreased berrybleaching only of 'PrimaRed' grapes. Q uality observations differed significantly among varieties (Table 4).

\section{Discussion}

Methyl bromide fumigation did

Table 4. D ifferences in quality among grape cultivars independent of methyl bromide fumigation. The methods of evaluation and units of each measurement are described in Table 1 . G rapes were stored 2 months at $0{ }^{\circ} \mathrm{C}\left(32^{\circ} \mathrm{F}\right)$ before fumigation and 2 weeks at $5^{\circ} \mathrm{C}\left(41{ }^{\circ} \mathrm{C}\right)$ plus $1 \mathrm{~d}$ at $20^{\circ} \mathrm{C}\left(68{ }^{\circ} \mathrm{F}\right)$ after fumigation $(1.0 \mathrm{~mm}=0.039$ inch).

\begin{tabular}{lccccccc}
\hline Cultivar & $\begin{array}{c}\text { Stem } \\
\text { condition }^{2}\end{array}$ & Shatter & $\begin{array}{c}\text { Cracking } \\
\text { (no.) }\end{array}$ & $\begin{array}{c}\text { Decay } \\
\text { (no.) }\end{array}$ & $\begin{array}{c}\text { Internal } \\
\text { browning (\%) }\end{array}$ & $\begin{array}{c}\text { Bleaching } \\
\text { injury }\end{array}$ & $\begin{array}{c}\text { Firmness } \\
\text { mm }\end{array}$ \\
\hline Ruby Seedless & $3.3 \mathrm{a}$ & $0.71 \mathrm{a}$ & $1.6 \mathrm{a}$ & $3.0 \mathrm{a}$ & $16 \mathrm{a}$ & $2.8 \mathrm{ab}$ & $3.2 \mathrm{a}$ \\
Red Globe & $4.3 \mathrm{~b}$ & $0.14 \mathrm{~b}$ & $0.7 \mathrm{~b}$ & $1.0 \mathrm{~b}$ & $9 \mathrm{a}$ & $2.8 \mathrm{~b}$ & $2.4 \mathrm{C}$ \\
Prima Red & $3.7 \mathrm{C}$ & $0.65 \mathrm{a}$ & $0.6 \mathrm{~b}$ & $1.4 \mathrm{~b}$ & $80 \mathrm{~b}$ & $2.5 \mathrm{a}$ & $3.0 \mathrm{~b}$
\end{tabular}

zM eans within columns followed by unlike letters are significantly different $(P=0.05)$ by Fisher's protected LSD.

yE valuated after 4 weeks at $5^{\circ} \mathrm{C}\left(41^{\circ} \mathrm{F}\right)$ after fumigation. 
not affect any quality parameter of the table grapes in our tests, and our results are similar to those of Phillips and coworkers (1984) who evaluated the impact of the fruit fly methyl bromide schedule on the quality of 'Thompson Seedless', 'Perlette', 'Flame Seedless', and 'C ardinal' grapes. Several aspects of our study differ from that of Phillipsand coworkers(1984): weevaluated ahigher methyl bromide dose and westored the grapes for 1 month after fumigation, rather than $6 \mathrm{~d}$, before we assessed internal browning. Because internal browning requires time to develop ( $N$ elson and Spitler, 1982), we evaluated internal browning after a period that simulated the duration and temperatures typical of export marketing. Several authors reported the development of internal browning of grapes and other fruit to be associated with methyl bromide fumigation (Liyanage et al., 1993). Audaand coworkers (1977) reported that methyl bromide fumigation exacerbated internal browning of grapes but was not the cause of the disorder itself, and that browning increased with longer storage times. Nelson and Spitler (1982) observed internal browning of 'T hompson Seedless' berries after fumigation with 32 $\mathrm{g} \cdot \mathrm{m}^{-3}\left(2 \mathrm{lb} / 1000 \mathrm{ft}^{3}\right)$ of methyl bromide for four or more hours when evaluated after 2 weeks at $0{ }^{\circ} \mathrm{C}\left(32^{\circ} \mathrm{F}\right)$ and $1 \mathrm{~d}$ at $20^{\circ} \mathrm{C}\left(68^{\circ} \mathrm{F}\right)$. They stated that factors, in addition to methyl bromide fumigation, can cause the browning of the berries, such as delayed cooling, high temperatures, slow cooling rates, long storage periods, extended market period and injury from rough handling. Furthermore, they found that these stress factors are additive: one stress may not cause visible browning, but in conjunction with one or more otherfactorsthebrowning may become evident. We observed some browning among the berries, particularly 'Prima Red' seedless, but it was not associated with methyl bromide fumigation and may have occurred during the long storage ( 2 months) of thegrapesused in our tests. Also, internal browning is not as readily apparent in highly pigmented cultivars as it is with less pigmented cultivars such as 'Thompson Seedless'.

Packaging influenced the dosage of methyl bromide within the boxes. EPS boxes absorbed more methyl bromidethan did TKV boxes, although the available dosage was within the minimum required for control of mealybugs. $\mathrm{H}$ arris et al. (1984) showed more methyl bromide was sorbed by the EPS than TKV or fiberboard boxes, and that after fumigation, significantly more methyl bromide was released from the EPS boxes during aeration. In their work, methyl bromide dosages with grapes packaged in TKV or fiberboard boxes, that were sufficient to obtain minimal levels required for the control of fruit flies for quarantine purposes, were too low when applied to EPS packages. U nder commercial conditions, it may benecessary to separatethegrapes according to package type and increase the methyl bromide dose applied when EPS boxes are fumigated.

In this work, we show for the first time that methyl bromide fumigation using the USDA-APH IS mealybug schedule $\left(64 \mathrm{~g} \cdot \mathrm{m}^{-3}\right.$ or $4.0 \mathrm{lb} / 1000 \mathrm{ft}^{3}$ for $2 \mathrm{~h}$ ) did not injure the grapes by any of the measures of quality applied, and the risk of berry injury by this treatment is probably low. This risk is further reduced if thegrapesarepromptlycooled after harvest, storage periods are not excessive, and rough handling isavoided.

\section{Literature cited}

Auda, C.M., H . Berger, A. Reszezyuski, A. Adriana, and A. L izana. 1977. Pardeamiento interno de uvas Sultanina. Inv. Agricola (Chile) 3:43-49.

H arris, C.M ., J.M . H arvey, and D.C. Fouse. 1984. Penetration and retention of methyl bromide in packaged table grapes. Amer. J . Enol. Viticult. 35:5-8.

Liyanage, C., D .A. L uvisi, and D .O . Adams. 1993. The glutathione content of grape berries is reduced by fumigation with methyl bromide or methyl iodide. Amer. J. Enol. Viticult. 44:8-12.

N elson, K.E. and G. Spitler. 1982. Postharvest handling factors affecting the market quality of Chilean table grapes in U nited States markets. Blue Anchor 59:16a-16d.

Phillips, D.J., R.K. Austin, D.C. Fouse, and D.A. M argosan. 1984. The quality of earlyseason table grapes fumigated with methyl bromide and sulfur dioxide. $\mathrm{H}$ ortScience 19:92-93.

U nited States Department of Agriculture, Animal and Plant $\mathrm{H}$ ealth Inspection Service, Plant Protection and Q uarantine. 1996. Treatment manual. vol. 1. Schedules. U SD A-A nimal PlantH ealth I nspection Ser., Plant Prot. Q uarantine, Riverdale, M d. 